$1-1988$

\title{
A New Pietism: Hegel and Recent Christology
}

\author{
Paul F. Lakeland \\ Fairfield University, pflakeland@fairfield.edu
}

Follow this and additional works at: https://digitalcommons.fairfield.edu/religiousstudies-facultypubs Copyright 1988 University of Chicago Press

Also available: http://www.jstor.org/stable/1202244

\section{Peer Reviewed}

\section{Repository Citation}

Lakeland, Paul F., "A New Pietism: Hegel and Recent Christology" (1988). Religious Studies Faculty Publications. 93.

https://digitalcommons.fairfield.edu/religiousstudies-facultypubs/93

\section{Published Citation}

Lakeland, P. "A New Pietism: Hegel and Recent Christology," Journal of Religion 68.1 (1988), pp. 57-71.

This item has been accepted for inclusion in DigitalCommons@Fairfield by an authorized administrator of DigitalCommons@Fairfield. It is brought to you by DigitalCommons@Fairfield with permission from the rightsholder(s) and is protected by copyright and/or related rights. You are free to use this item in any way that is permitted by the copyright and related rights legislation that applies to your use. For other uses, you need to obtain permission from the rights-holder(s) directly, unless additional rights are indicated by a Creative Commons license in the record and/or on the work itself. For more information, please contact digitalcommons@fairfield.edu. 


\section{The Journal of Religion}

ground. ${ }^{68}$ Unless Christians at least attemp! to show such constant attentiveness not only to Jesus' story but to Israel's also, then in their talk about God's action, trying to identify some act as being characteristically "divine" will be perhaps the least perplexing uncertainty confronting them, For even more disturbingly, they, will encounter abiding doubts whether in uncing the name "God," they mean and refer to the satne. claimed, after all, to be their story, too.

is See Michacl Goldberg, Theology and Narrative: A Critical Introduction (Naskville, Tenn. Abingdon Press, 1982), chap. 6.
A New Pietism: Hegel and Receńt Christology*

Paul Lakeland / Fairfeld University

Discussion of the putatively Christian character of Hegel's philosophy focuses on the question of the relation Hegel envisages between philosophy and religion. ' There are those who argue that his philosophy is simply a foundational Christian metaphysic, a species of the philosophy of religion. ${ }^{2}$ Others are no less convinced that Hegel's system is the end of religion, ${ }^{3}$ and there are innumerable variations between the two extremes. This discussion dates back at least to the years immediately following Hegel's death in 1831, when those who interpreted him as a Christian philosopher and those who thought of him as at least implicitly atheistic were polarized into the so-called right and left wings of Hegetian philosophy. ${ }^{4}$ Classical right-wing interpretation saw Hegel as a metaphysician, thus leaving room for the identification of the Hegelian absolute with the Christian God. On the left, Hegel was (at the "highest") an ontologist, and the Christian god could not survive. Still today, though in a severely modified way, it is possible to talk in mean-

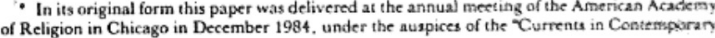
Christology" group.

I This, perhaps the most vexed of all interpretative questions nbout Heget, is of necrestity da.

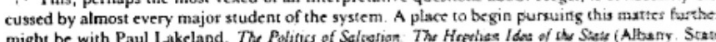

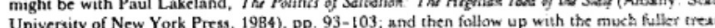

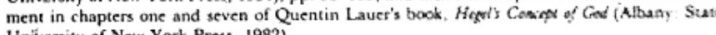
University or New York Press, 1982 .

This point of view, see Laveri; and James Yefikes. Tta

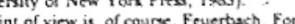

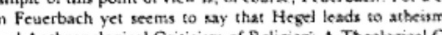

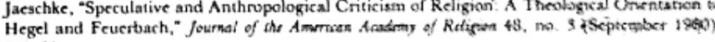
$345-64$. A A recent work by John Edward Toews shows very convincingly chas the onteto of this diviation

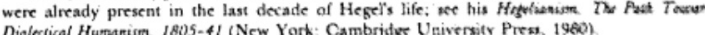

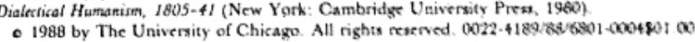

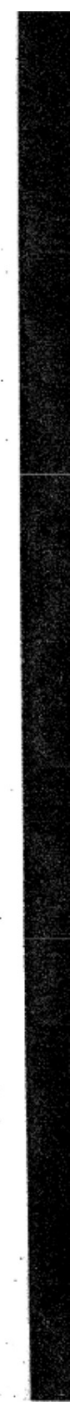




\section{The Journal of Religion}

ingful terms of right and left, even if those seeking a middle way have rown in strength. ${ }^{5}$

Hegel envisages religion as the penultimate moment in the progress of the human spirit toward its apogee in philosophy as the highest of human activities. Both religion and philosophy have truth as thei the latter as concept (Begriff). Religion is "sublated" (aufgehoben) in philosophy, that is, somehow superseded, and yet mysteriously preserved in this cancelation. The problem raised by the notion of sublation (Aufhebung) is simply expressed: is religion reduced to philosophy in this process, or is philosophy employed to explicate the truth religion contains? Clearly, the interpretation of Hegel as more or less religious or secular rests on the answer to this question. Was he "the Christian philosopher par excellence, ${ }^{, 6}$ or was he a proto-Marx who had not yet discovered his nerve?

A curiosity of the present moment in Hegel studies, and the stimulus to the current paper, is the shifting significance of "right" and "left" in the assessment of Heger's mature thinking on religion. There was a time when the right could confidently be assumed to be Christian, while the left could with equal certainty be taken to be atheistic. Rightwing interpretation basically consisted in showing how Hegel remained a philosopher of religion, indeed, one of an "isolated order or priests" charged with the preservation of the truth content of religion at a time when theolons wering in

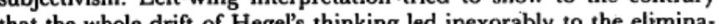
ion of religion and the installation either of reason or of material totaltity in its place.?

3S See Peter Hodgson's essay, "Georg Wilhelm Friedrich Hegel," in Ninetenth Century Retigious Thought in the West, ed. Ninian Smart, John Clayton,
(Cambridge: Cambridge University Press, 1985), l:120. "Errol Harris's opinion, in his "Hegel and Christianity," Ouw of Minerea 13, no. 4 (Jume 1982): 1. Philesophly of Retigion that the issue of the significance of religion and its relation to philosophy is thest directly addressed. It is also here that Hegel makes fullest use of Christian theological anbols, including that of the Incarnation. Heget lectrite on the philosophy of religion four nd student transeripts were available were rapidy gathered logether and edited for the Watk by

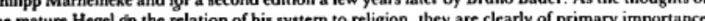
for anyone who would utilize Hegel's work in doing theology. The lectures are now finally available in a reliable edition, published simultaneously in German, English, and Spanish under the joint editorship of Walter Jaesshke, Peter Hodgson, and -8icardo Terrara. The German three (Berkeley and Los Angeles: University of California Press, 1984-86). A further complete and, it is to be hoped, definitive critical edition of the German text will eventually appesas,
- Hegel and Recent Christology

Today, the labels of "left" and "right" must be assigned, if at all, with Today, the labels of In particular, it is no longer possible to assert or much more subtlety. In particular, it is no longer possible to arsert or right-wing end of the spectrum. In the late twentieth century, and largely thanks to Hegel himself, a left-Hegelian Christian is more than a possibility. One could even imagine a dispute between a Christian Hegelian, inspired by Hegel's incorporation of the "death of God" into his philosophical system, and a right-wing Hegelian committed to the view that Hegel's system, while it had used Christian symbols, had rapidly transcended any dependent relationship. One might then be treated to the spectacle of the left defending a religious interpretation of Hegel's work against the secular drift of the right. Of course, this would be due as much to a shifting understanding of the meaning of the Christian religion as it would to changes in Hegelian scholarship, though it should be added that the movement within religious thinking is at least partially inspired by the legacy of Hegel.

1 propose in this article to examine one example of the shifting configurations of right and left wing religious interpretation of Hegel. shall begin by outlining the role of religion in the mature Hegelian sys. tem and the traditional positions of right and left interpretation. Then I shall examine in some detail two recent attempts, one from the right and one from the left, olscholars whose work in theology has cleany been conducted in dialogue with Hege's phlosophy of religion by whose atticudes to Hegel demonstrate the reconiguration or tighe and different ways and have learned from Hegel in accordince with their positions on the right and the left, there is a curious convergence in the way they finally distance themselves from him. Both criticize Hegel for reducing religion to philosophy, and I shall designate their common position a "new pietism." Hegel's defense of his work against the pietism of his own times will provide the occasion for a concluding section in which a differing,reading of Hegel' will reveal evidence of his continuing value to Christian theology.

Even a superficial reading of Hegel's works should excite the imagina tion of the theologian. As Walter Kasper has written, because chris tology has to inquire into, existence in general, "a Christian is so to speak compelled to become a metaphysician on account of his faith. "7

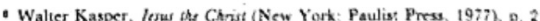


The Journal of Religion

Hegel's system, in outward appearance at least, is both clearly Christian and undoubtedly metaphysical. However, Hegel's suitability to the theologian's purpose goes far beyond this. In Hegel's mind the struc ture of self-consciousness, the structure of reason, and the structure of Spirit are identical, and, if we were to seek out a religious symbol tha would represent that structure perfectly, it would be the Christian symbol of the Trinity. For reasons such as this, many thinkers would concur in Errol Harris's judgment quoted above, that Hegel is the Christian philosopher abpve all others.

Hegel's philosophy is not only trinitarian in shape. It also leans heavily on the figure of Christ and the notion of the Incarnation. Such emphases, of course, follow from the trinitaran strecter secause, since Heg any other datum of Christian revelation withou question, the entry into trinitain thount, way of the expression of the absolute in history. As James Yerkes has shown in his outstanding study. The Christology of Hegel it is importan to take seriously 'Hegel's statement that the crucified Christ is the speculative midpoint of his system 9 'It is clearly mot necessary to accept 'Hegel's own valuation of his philosophy or of Christ, but that he believed the Incarnation to be of central importance to his thought is beyond doubt.

As we have said, Hegel considers the structure of self-consciousness, of the concept, of reason (i.e $e_{9}$, nondiscursive knowledge), and of Spiri to be identical. This structure is most clearly exemplified by the paradigm of self-knowledge. Truly to know the self entails the ability to identify a difference between the self and that which is not-self. The process of coming to self-knowledge is then a process of moving from an inchoate self-possession to a knowledge of the other, as other (nega tion), to a consequent recognition that 1 am other than other, that is, am I (negation of the negation). In becoming a true knowing subject, the individual passes through a moment of dependence on the other, on what it is not, at which moment of dependence lies the pivot beyond which begins the return to self. This structure is appropriate to the theoretical discussion of the birh of self-cony af opment, e.8., of he human infals, to any act of known. Spirit is not some impersond substance but subject. Spirit is Subject,

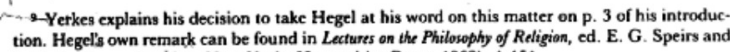
J. B. Sanderson (reprint, New York: Humanities Press, 1962), 1:151.

10 The structure is also used by Hegel phylogenetically, to explain the progress of Reason in
Hegel and Recent Christology fully self-conscious knowing achieved through self-othering and return to self.

To argue for a close relationship between Hegel's Spirit and the Christian God involves a view of the Christian God that not all Christians would recognize, just as it requires an interpretation of the Hegelian Spirit that not all Hegelian scholars can stomach. ${ }^{11}$ In Hegel, the Christian God achieves the moment of negation in the creation, then becoming present in the other as finite spirit, in Jesus Christ. In Christ, God is both other than God and yet God. The otherness of God is most complete, the point of total negation of self is reached, in the subjection of Christ to death. In the crucifixion God is dead. However, the furthest point of negation is the pivot in the return to self; from cruciuxion follows resurrection, as the Spin come

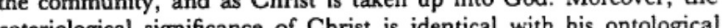
soteriological signifcance of Christ is identical wh the of Spirit and finite spirits precisely by being the unique and normative example of that relat

This outline of Hegel's dependence on Christian symbols is not the of reality is clearly in a tense dependent on Christianity for the fullest possible representation of what Hegel called the concept of religion. It remains, however, representation and requires the advent of speculative philosophy for its conceptual elucidation. But, as Walter Jaeschke/has perceptively argued, the elucidation of the theological symbol is the comprehension of religious truth by philosophy. ${ }^{12}$ In comprehending revelation, the philosopher seems to be giving the priority to human reason over the specificity and supposedly privileged nature of religious revelation.

The right/left division in Hegel studies is perhaps most marked among interpreters whose principal interest in Hegel is in his religious thought. On the right, the fascination with Hegel seems to be largely with the idea of a system. Since Hegel's system can with some justification be claimed for Christianity, its conceptual rigor and its confiden claim to comprehensiveness are attractive to those of a more scholastic
disposition. In addition, Hegel's clairn to read history as the medium in

(a) God/Spirit is Hodgson's essay on Hegel in Smart of at pp 81-121. Nithoush the whode of

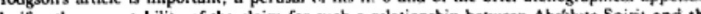
Christian God.

12 See Jaeschke, esp. p. 354. 


\section{The Journal of Religion}

which Spirit comes to fuller self-possession conforms neatly to the salvation history perspective of much Christian thought. For these reasons, if for no others, the right is predominantly Catholic. ${ }^{13}$ The left, however, is left because it retains that fascination with negation, with Marx were both attracted. However, Hegel's focus on the crucified God has to be seen as at least partially inspired by that of Luther. In Hegel's thought, the death of God is at one and the same time an announcement of radical human autonomy and a profound theological statement. It is this tension and ambiguity that explains to a large extent the Protestant interest in Hegel. Hegel's thought seems to allow for faith despite the death of God, indeed, it even incorporates atheism as a moment in the dialectic. 14

The christological orientation of left and right follows much the same pattern. From the right, the incarnation of God in Christ is seen as the linchpint af a Christ thought that realitys as a whole could be explained. On the left, Hege's mystery, one in which sheer atheism and the divinization of the hume race are locked in a strug e within a system that is a historically conditioned and ultimately dispensable ontology. The right takes Hegel seriously on his own terms, but at the risk of seeming anachronistic. The left is freer with Hegel, mainly unconcerned with his larger schema, but perhaps allowing Hegel more of a voice in a distressed world he did not himself foresee,

Only with the Hegelian renaissance of the past thirty or so years has it become intellectually respectable to take anything other than a dismis-

13 See, e.g., in addition to Lauer, many of the essays collected in Hegel at la theologin conkmporaine: Labsotud dans Thistoire? (Paris: Delachux \& Niestle, 1977). The work is edited by no Louis Rumpf, among others (subsequendly cited as " $R$ ump "? 14 From the Protestant "left" the list is a little longer and more Germanic. Walter Pannenberg's

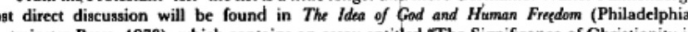
the Philosophy of Hegel" (pp. 144-77), but much of Pannenberg's other work continues the

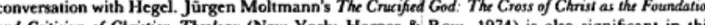
and Cnitism of Chistian Theology (New Vork. Harper \& - their thinking up to date. A christology decply influenced by Hegecian thought patterns is

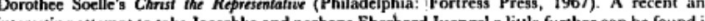

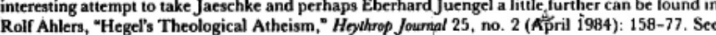

Hegel and Recent Christology

sive attitude to the role of Christianity in Hegel's writings. The initia tive here was largely that of a group of French Catholic thinkers, principally Albert Chapelle, Andre Leonard, and Claude Bruaire. Chapelle's book, Hegel et la religion, was the most significant contribution, combining as it did a deep and scholarly knowledge of the texț, fascination with the idea of a system, and conviction that Hegel was a truly Christian thinker. ${ }^{15}$ More recently, Chapelle has written clearly and briefly of his valuation of Hegel for defending. Christianity as the consummate religion. "Characteristically for this Catholic school, he subordinates Hegels other conclusions: We shall Cele the specularive thought to a marecise, is that of Catholic theologian. ${ }^{1}$ ? In the same volume essays, Leonard concludes his article with the opinion that Hegel's view of history needs to be complemented by "a logic which is closer to that of ecclesial tradition. ${ }_{18}$ Bruaire defends Hegel from the perversity of of ecclesial who would interpret him atheistically, adding that great berefits would arise from inserting Hegel's approach to religion into the context of " $\mathrm{z}$ way of thinking that is more open and faithful to the thought of revelation. ${ }^{n} 19$

The most recent exponent of this rightist Catholic approach is Emilio Brito. Brito's position is laid out at considerable length in two recen books, Hegel et la tache actuelle de la chrstologie, and La chinstologie de Hezest Verbum Crucis. ${ }^{20}$ The latter amplifies the former and shows no discernible variation in interpretation. In the earlier work Brito discusses three Hegelian chrissogies, which he links to three different works of the corpus. A subjective christology is developed in the. Phemomimology of Mind, an objective christology in the Lectures on the Pathosophy of Religion, and an "absolute" christology. in the Engelopedia of the Philosophical and critique of contemporary ehristology. In the second book he ampli Praxis (Zagreb), 1971, pp. 203-14

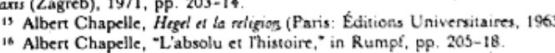

io Albert Chapell, 1 , lbid., p. 205 .

io André Leonard, "Labsolu et Thistaire selon Megel," in Rumpf, p. 95 .

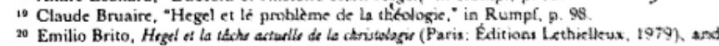
La christalogie de Heggt: Vertum Crasis (Paris: Beaurhesne, 1985)

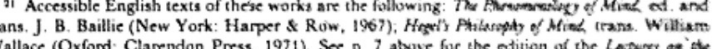
Phitasphaty of Retigien 


\section{The Journal of Religion}

fies his justification for the distinctions and follows with an outline of a

"post-Hegelian" christology. La christologie de Hegel: Verbum Crucis, a philosophy of concept is systematically subordinated to a theology of symbol. ${ }^{22}$ Reason, says Brito, is transcended in prayer, and it is prayer that he holds to be the primary mode in which the truth of faith can be expressed symbolcally. ${ }^{23}$ Though informed by his study of Hegel, the structure of Brito's christology comes from his close acquaintance with the thought of Ignatius of Loyola. The dynamics of Ignatian prayer - gift, presence, work, and communion, in Brito's formulation-are paralleled by the dynamics of christology-kenosis, incarnation, passion, resurrected glory. Hegel's rationality is simply too closed-ended for Brito, and "the dynamics of reedom ends in emptying out all contemplative reality. "24 Brito clearly believes that theology cannot be contained within a rational system. The notion of necessity, he thinks, restricts the radical freedom of God. In Hegel's thought, the process of Spirit needs the dependent for fullness of self-comprehension on that which God has created. Moreover, since Hegel's God dies on the cross and is resurrected in the faith of the community, the pivotal point has been reached, and God's return to self is in principle complete. Hence, according to Brito, there is no role for a parousia in Hegel's thought: a further return to the world would be irrelevant.

In the discussion of kenosis the extent of the differences between Brito and Hegel becomes apparent. ${ }^{25}$ Not only is Hegel's idea of kenosis one of a necessary stage in Spirit (hence, in God), but it is expressed as a negative product of love, a negativity out of which. Spirit truly emerges. For Brito, kenosis has to be seen as a product of disinterested love. ${ }^{26}$ Moreover, created nature for Hegel seems only to achieve its purpose in being negated, in being the negative moment in the process by which God returns to self. God, says Brito, surely does not need to destroy "son receptacle precaire." 27 On the question of the hypostatic union, Hegel is accused of following radically Lutheran lines, seeing the Logos as union of God and human being rather than as God. On the matter f preexistence, both of Trinity in general and of the Logos in partic-

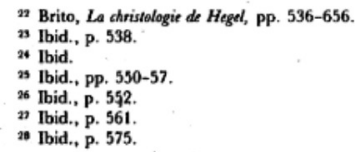

Heğel and Recent Christology

ular, Hegel gets good marks, although the preexistent Logos/Trinity is an abstraction to be overcome in a concrete actualization in which God is fully revealed. Hegel's christology, says Brito, is a kind of "reverse Arianism" in which the Father is subordinated to the more concretc moments of Son and Spirit. ${ }^{29}$ In its turn, the earthly presence of Jesus is gone forever with the coming of the Spirit, and Brito argues that this is the most anti-Christian aspect of Hege's christology. ${ }^{30}$ The selfconsciousness of Jesus Christ is relativized to the complete knowledge of Spirit and to the faith of the community.

There are good reasons to sympathize with Brito's point that theology needs more room for novelty and the freedom of God than a philosophy of concept can permit. Hegel's God is certainly philosophicaily comprehended, and as jaeschike has pointed out in another context, that is hard for the Christian theologian to accept. However, Hegel wishes only to claim that the freedom that is not possible to God is that of sheer caprice, the freedom that would be self-contradictory and thus impossible in the case of Spirit itself. Overall, Brito's strug. gle with Hegel teaches an important lesson about the linitations

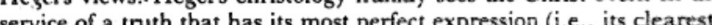
in the categries of speculative philosophy. For Hegel, unlike Brito, the concept surpasses the symbol. 33

Hegel, it will be remembered, was of the opinion (probably rightly) that in view of the lack of intellectual nerve among the dominant theologians of Pietism and Romanticism in his own terms, theology that waz unafraid to ask the truth question about God could only be found withia speculative philosophy. Theology in the narrow sense took too much ior granted and would not or could not reexamine. its own presuppositisns. Foundational theology, he felt, had not only given way to systematic theology but also to a form of systematic theology that saw no need for philosophical rigor and was content to shuttle the concepts inherited from the tradition. The twin evils Hegel saw himself comba: ing were those of subjectivisin and confessionalism.

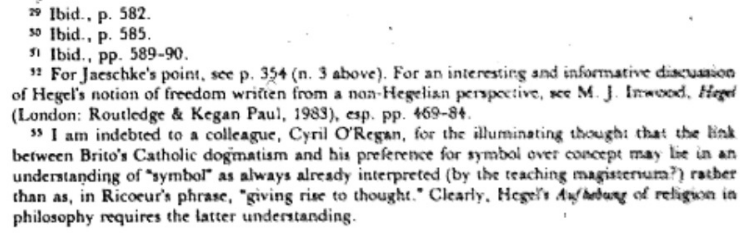


The Journal of Religion

It seems probable that Brito's final refusal to take what we might cal the "leap of thoughe" places him in a position so close to the Pietism of Hegel's time that he is open to the criticisms of that kind of theology expressed by Hegel. When Brito reaches his constructive theological proposal, he lapses into a contemplative, mystical approach that seem to find no place for the kind of questioning of presuppositions that Hegel's method emphasizes. If prayer is indeed the heart of theology, as it well may be, prayer does not show what is good and bad theology. Here the real divergence lies, because where Hegel (and we) would sophical rigor, and where others would make a case for the control the scripture principle over what theolo can say. Brito remans woodenly faithful to the tradition from which he emerges and resubmits the . of institutional $\mathrm{Cag}$ hrom which he has

The heart of Brito's critique is his resistance to the idea that the christological understanding of scripture and tradition can be filtered through a philosophical system that does not derive from the same hallowed sources. Brito's christology remains Hegelian in the way in which he tries to balance the subjective, historical, and absolute standpoints, in which he seeks a comprehensiveness of approach for which there is no greater model than Hegel. In the final analysis, however, Brito seems to fall into the same category as the Rornantics and Pietists of Hegel's own day. Because of presuppositions about the nature of theology, above all because of an unwilhngness to subject the theological traditions itself to critical scrutiny, he must exclude on a priori grounds the legitimacy of the Hegelian approach. For Brito, the Aufhebung of religion in philosophy is nothing more than the conceptual explication of something that not only continues to exist but also retains its full richness. The Aufheoung is effectively denied. Hegel's work is "only" philophy of religion and, als such, inadequas to

III

Although Hegel figures far less prominently in Eberhard Juengel's most recent work 35 than in either of Brito's books, Juengel's christolog "The, introductions to both of Brito's works situate, him firmly in the Chapelle/Leonard
Bruaire tratidition, which would seek to put Hegeg in a larger" (i.e.e., more Catholic) context.

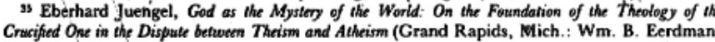
Publishing $\mathrm{C}_{0}$., 1983).
Hegel and Recent Christology

undoubtedly the more sympathetic to his great predecessor. Juengel's Lutheranism and his overriding theological concern mean, of course, that he too cannot go along with Hegel on the Aufhebung of religion in philosophy. In fact, from Juengel's point of view, Hegel is to be applauded for having engineered what is almost diametrically the opposite, namely, the incorporation of a central Lutheran insight into philosophy. Hegel found a place for the death of God in his philosophy without implying the demise of the philosophical absolute, just as Luther's notion of the death of God is not equivalent to the end of God. ${ }^{36} \mathrm{It}$ is this that makes Hegel so profoundly important for Juengel and, perhaps, for all theologians concerned with belief in a secularized world. By putting the death of God at the heart of an idealis philosophy inspired (to say the least) by Christian symbols, Hegel demonstrates that atheism is not so me a philo as a moment in

negation through which the Resurection christological investigation. Juengel's major aim in his long and rich christological investigation. Juengels major aim in his long and rich treatment is to shod. The metaphysical notion of God was of some value but in fact is at the root of atheism since in the end God is made subordinate to the human mind (Brito's subjective christology again). Access to the God who is "more than necessary" (i.e., whose presence in the world is gratuitous, given out of a love that cannot be constrained in logical categories) is via the Word of God in history, in Juengel's view. He goes on to argue that the privileged historical moment of the revelation of that Word is the "theology of the crucified One," the God who is dead on the cross."

Juengel's dialogue with Hegel is by no means the center of his book. It occupies, in fact, no more than about forty pages, ${ }^{38}$ and it concludes in a distancing from Hegel since Hegel's attempt to use philosophy to rehabilitate theology is unacceptable to Juengel. Nevertheless, the theology of the crucified espoused by Juengel owes a lot to this dialogue with Hegel. Juengel writes approvingly, for example, of Hegel's designation of the death of Jesus as the parting of the ways between belief and unbelief. Without faith, the death of Jesus is like the death of Socrates. "Faith, on the ohy hand," Juengel gocs on, "perceses, in

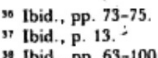


The Journal of Religion

history of Christ. ${ }^{{ }^{39} 9}$ Later in the book, beyond the explicitly Hegelian section, the legacy is evident: "The self-relatedness of the deity of God takes place in an unsurpassable way in the very selflessness of the incarIt is not a second thing next to the eternal God, but rather the event the deity of God. For that reason, the economic is the immant Trinity and vice-versa. And thus the crucified one belongs to the con cept of God ${ }^{n} 40$ Such a comment could not have been written before Hegel.

Juengel's difficulties with Hegel, like those of Brito, seem in large part to arise from attempting to impose theological a prioris on his thought. Because of Hegel's failure, as Juengel sees it, to recognize that for Luther the communicatio idiomatum extends only to the unity of divine and human in Jesus Christ and cannot be made into a universal, the logic of his position leads him to postulate the divinization of human beings. Against Juengel, however, it has to be pointed out that Hegel's project was not to be faithful to Luther. He was engaged in a philosophical re-presentation of the ideas that thus far in history had been most successfully presented in the symbol-system of (German Protestant) Christianity. "Incarnation" is both a moment in the life of God and the explanation of the existence of finite spirits. If this is unfaithful to To

To say that Hegel does not agree with Luther does not of cours

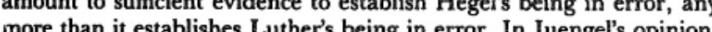
Christ "is both divine and human in that he prevents becoming God and liberates him to be nuan and nothing other fhan man "*1 Why so? Hegel would surely reply (as might Karl Rother than the Incarnation is the revelation that there is no definitive and absolute gulf between divine and human. There is undoubtedly a difference, above all in the fact that although God can choose to become huma, human being cannot choose to become God. Nevertheless, God's adoption of one human being to be God amoints to the clear revelation of a relationship of nonexclusiveness between God and human beings. That this formulation would be unacceptable to Juengel is evidence in his case of what we have already seen in that of Brito, namely, a shyin away from the Hegelian Aufrebung of religion to philosophy. Unlike Brito, however, Juengel admires the philosophical step of the incorpo-

$$
\begin{aligned}
& \text { so Ibid., p. } 91 . \\
& \text { s" Ibid. } \\
& \text { t" Ibid, p. } 95 .
\end{aligned}
$$

Hegel and Recent Christology ration of a theological notion in philosophy, but only the symbol of the death of God, not the whole of religion, is aufgehobem.

Juenel and Bir fundamental theological orientations as Catholic and Protestant. There is a disappointingly dogmatic element in the work of both, not only in their critique of Hegel (Hegel is insufficiently Lutheran or insufficiently Catholic) but also in their a prioristic options for Lutheranism or for Catholicism. Moreover, there is a curious convergence in the way in which both finally part company with him. Behind their recourse to a relatively uncritical dogmatism lies the unwillingness of these particular theologians to grant philosophy the kind of role that Hegel claim for it. This "new pietism" fails to take seriously the ability of Hegel's philosophical program itself to provide resources for meaningiul theological insights. In the remainder of this article I propose to consider whether Hegel's own understanding of the religion/philosophy relation can be christologically and theologically valuable.

Hegel's Aufhebung of religion in philosophy means neither the. reduction of religion to philosophy nor the mere description in philosophical terms of what religion is and does. To accept either of these approaches is to opt for facie evidence against the validity of such a univocal perception. What we have to seek is some form of compromise that pays more attention to the dialectical character of Hegel's thinking.

Philosophy brings the truth of religion to explicit constiousness. It does not remove or reduce that truth. It is truth presented in a differen mode, that of the concept rather than the symbol or representation. Indeed, philosophy owes to religion the fundamental symbols that inspire it in its conceptual explication of reality. The interrelations and mutual need of Idea, Nature, and Spirit, for example, are explained on the model of the symbol of trinity. Just as all three "modes of subsistence" of the Christian God are interdependent and in a sense equat so all three moments of the Hegelian system are similarly related.

Although Hegel conceptualizes philosophical reality on the analogy of the Christian trinity, both philosophy and theology are done from the standpoint of finite spirits within the world (the moment of objective spirit, or human history). The "immanent" trinity of Christian and theology exist only within the objective moment. They are histor-

$r$ 


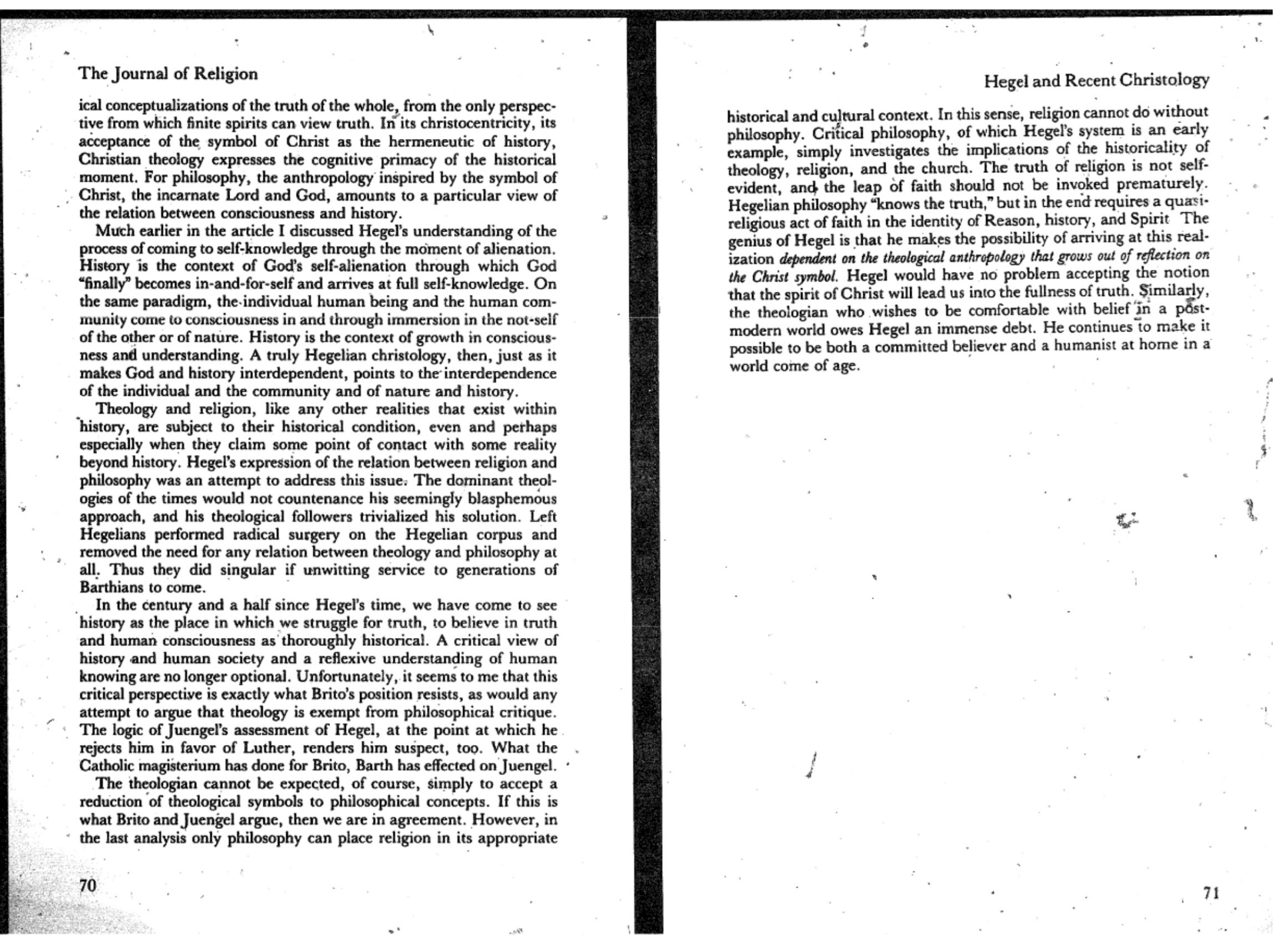


